\title{
Castle Pinckney
}

\author{
A. R. Wilson ${ }^{1} \&$ M. Schara ${ }^{2}$ \\ ${ }^{1}$ Historic Preservation Program, Clemson University, \\ College of Charleston, Charleston, South Carolina, USA \\ ${ }^{2}$ National Park Service, US Department of the Interior, \\ Washington, DC, USA
}

\begin{abstract}
Castle Pinckney, the oldest surviving fortification in Charleston, South Carolina, was built in 1809 on a small island in the city's harbor. It remains one of only three surviving examples of an American "castle," a rare type of transitional coastal fort, circular in form and lacking angular bastions. The fort played a minor role during the American Civil War and was subsequently decommissioned, passing through the jurisdiction of a number of different government agencies over the past 150 years. Due to lack of funding, Castle Pinckney has essentially languished in abandonment for over a century. In 2011, as a mitigative and educational effort, and as an effort to bring public attention to a significant endangered resource, a documentation project was undertaken of the fort by the Historic American Buildings Survey and by the Master of Science in Historic Preservation program of Clemson University/College of Charleston. Building on this effort, in 2012-2013 a national student design competition will be held to explore ideas for the adaptive reuse of the site.

Keywords: American castles, coastal forts, laser scanning.
\end{abstract}

\section{The history of Castle Pinckney}

\subsection{Early fortifications in Charleston}

\subsubsection{Colonial Charleston}

Charleston (originally Charles Towne) was founded in 1670 by Anthony AshleyCooper, one of the eight Lord-Proprietors appointed by Charles II for the new Carolina colony. The settlement was strategically located on the peninsula between the newly-named Ashley and Cooper Rivers, inside perhaps the finest 
natural harbor along the south eastern coast of North America. As the southernmost English continental settlement to date, Charleston, during its first decades, was in constant threat of attack from the Spanish in nearby Florida. Because of this danger, along with those from confrontations with Native Americans and from pirate raids, the early settlement was surrounded by a combination of brick walls and wood palisades. Although the city had expanded beyond this original enclosure by the middle of the eighteenth century, this area remains known today as the "Walled City" neighborhood [1].

\subsubsection{Charleston during the revolutionary war}

By the time of the American War of Independence (1776-83), Charleston had grown to become a thriving port and commercial center, the fourth largest city in the British colonies. Because of its prominence, an extensive, albeit temporary, system of fortifications was hastily constructed to protect the city, much of it designed by French emigré engineers (Robinson [2]). The first British attempt to seize Charleston, by General Henry Clinton in 1776, was repulsed. A second attack by Clinton, with a much larger force four years later, overwhelmed the city's undermanned garrison after a six-week siege, perhaps the most significant American defeat of the war.

\subsubsection{Fort Pinckney}

Following the war and the attainment of American independence, the new United States Congress in 1794 authorized the hiring of engineers to oversee the fortification of important seacoast cities. This effort became known as the "first system" of American forts (Robinson and Lewis [3]). The sums appropriated were small, however, resulting in the construction of impermanent works. Typical was the situation in Charleston, where four forts were authorized to guard the harbor. One of the forts was located on Shute's Folly, a marshy island located approximately one mile east of the city's waterfront in the mouth of the Cooper River. Built of $\log$ and earth construction, the fort was named in honor of Charles Cotesworth Pinckney (1746-1825), a prominent South Carolina planter and native Charlestonian. Pinckney had served as a general during the Revolutionary War, was a signer of the Constitution, and was then serving as the American ambassador to France. Built in 1798 at a time of potential confrontation with France, Fort Pinckney was essentially abandoned in 1800 with the easing of tensions between the two countries, and was subsequently destroyed in an 1804 hurricane (Ziegler [4]).

\subsection{The construction of Castle Pinckney}

\subsubsection{The second system of American forts}

Beginning with the reconstruction of Fort Mifflin, near Philadelphia, begun in 1795, the United States began to develop a more permanent system of coastal fortification. Known today as the "second system" of American forts, for the first time the new nation committed to building substantial fortifications of brick and stone masonry. Approximately thirty-two second system forts were built over a twenty-year period, although the nation still lacked a comprehensive 
defense plan [5]. Subsequent events, most notably the War of 1812 (1812-15) with Great Britain, would prove that many of the forts were constructed too close to the cities they were intended to defend. Today the second system is considered a transitional phase, leading to the "permanent system" of American forts begun in 1816 under the direction of the newly-established United States Army Corps of Engineers (Robinson [6]).

\subsubsection{Jonathan Williams}

Coincident with the development of the second system, the United States Military Academy (USMA) in West Point, New York, was established by Congress in 1802 as the nation's first engineering school. The school's explicit intention was the creation of a homegrown engineering corps, thus freeing the new nation from its reliance on foreign (typically French) expertise (Ziegler [7]). Major Jonathan Williams (1750-1815) was appointed by President Thomas Jefferson as the first superintendent of the new institution, as well as the Army's Inspector of Fortifications. Williams had spent most of the period 1770-85 abroad, first in England, and subsequently in France as secretary to Benjamin Franklin, the American ambassador. While in France he had studied both medieval castles, as well as contemporary fortification theories, in particular those of Marc Rene Marquis de Montalembert (1714-1800) [8].

Williams returned to the United States bearing a copy of Montalembert's La Fortification Perpendiculaire (1776). As opposed to the sprawling, polygonal, multi-bastioned fortifications pioneered by Sebastien le Prestre de Vauban in the seventeenth century, Montalembert was an advocate of "vertical" forts, compact in form and with multiple levels of casemates. The third part of his treatise was devoted to the design of circular forts. Williams realized the advantages of this type of fort for defending American coastal cities, where sites were often constrained and there was little need to defend from land attack.

\subsubsection{Castle Williams and Castle Clinton}

Williams had the opportunity to put these theories into practice with the design of a series of forts to protect New York Harbor. Several of the forts were circular in form, which Williams designated "castles" because of their evocation of medieval keeps. Construction of the eponymous Castle Williams, on Governor's Island, was begun in 1807. Three stories in height, Castle Williams was the first fully casemated fort in the United States. Castle Clinton, begun the following year, was built approximately 200 feet off the southern tip of the island of Manhattan. Castle Clinton was built in the form of a truncated circle, with the long, curved section of the fort facing out into the harbor and housing the gun casemates. The short, straight section of the fort faced land and was flanked by two curved, projecting bays. Both forts were built of stone (Lewis et al. [9]).

\subsubsection{Alexander Macomb and the construction of Castle Pinckney}

In 1807 Major Alexander Macomb (1782-1841), one of the first army officers to receive training at the USMA and a friend of Williams, was appointed engineer in charge of coastal fortifications for the Carolinas and Georgia, and tasked with 


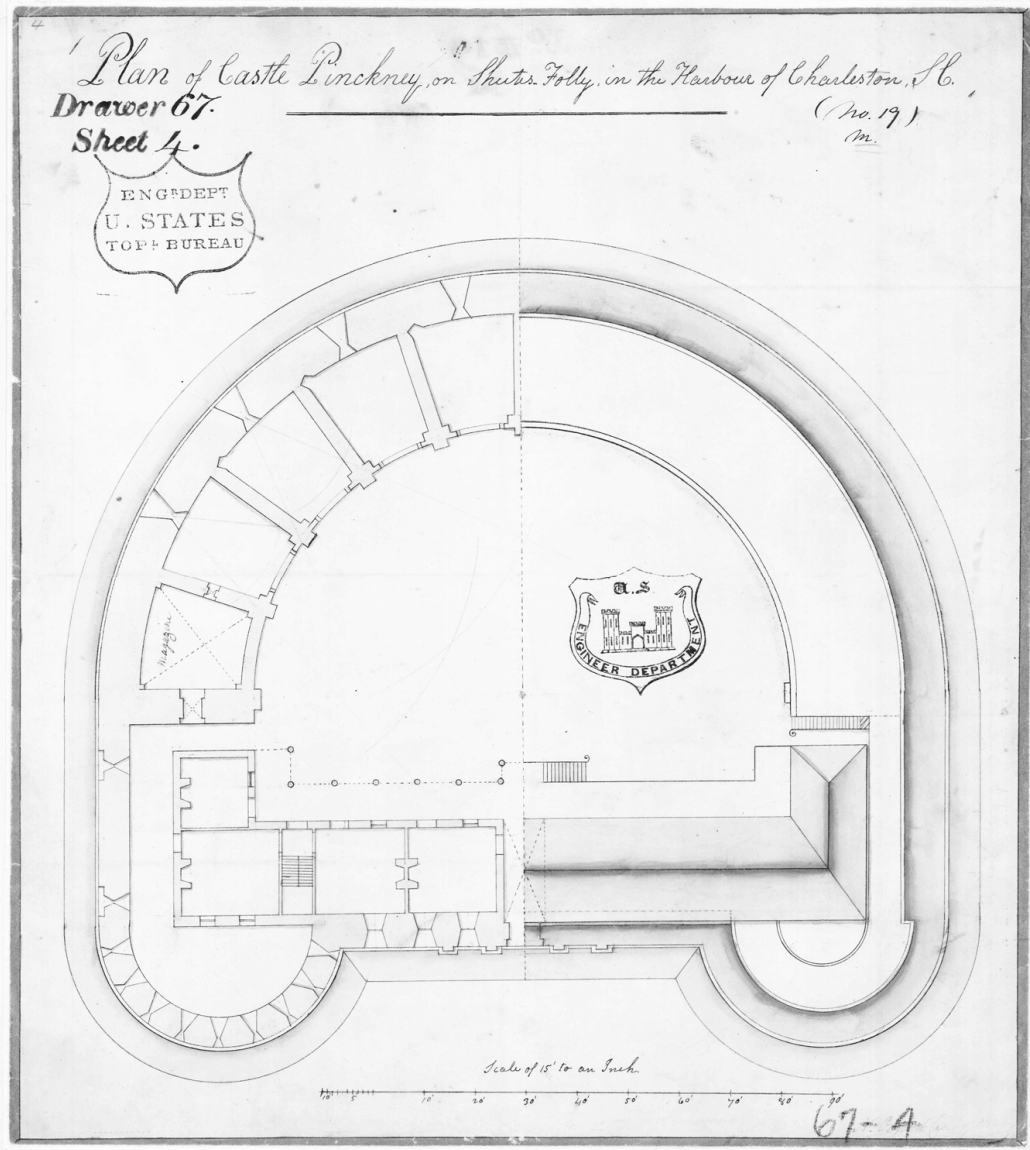

Figure 1: $\quad$ Plan of Castle Pinckney, circa 1809 (National archives and records administration).

upgrading the defenses of Charleston. After receiving the design from Williams for a new fort to replace the destroyed Fort Pinckney, Macomb began construction of Castle Pinckney in 1809. By 1811 the new fort was ready for the installation of armaments (Ziegler [10]).

Castle Pinckney was built of brick masonry construction, with its exterior walls approximately $15^{\prime}(4.5 \mathrm{~m})$ in height and approximately 7 ' 6 " $(2.3 \mathrm{~m})$ thick at the base. In plan, the fort was closely related to the design of Castle Clinton, laid out in the general shape of a "half-moon," with a $165^{\prime}$ ' $(50 \mathrm{~m})$ diameter. The sweeping, rounded section of the fort, oriented south toward the mouth of the harbor, contained eight casemates for cannon. Additional artillery was to be mounted en barbette on the terreplein above. The straight section of wall along the north side of the fort was flanked by two shallow, curved bastions, each with two levels of gun embrasures to provide protection for the centrally-located sally 
port. Barracks and officers' housing were located on the interior, along the north wall section.

\subsection{Castle Pinckney 1811-2011}

\subsubsection{Castle Pinckney 1811-61}

Although built to accommodate up to 200 men, Castle Pinckney was rarely occupied by more than 20 soldiers during the first few decades of the nineteenth century. No action occurred in Charleston during the War of 1812. Over the succeeding years a number of subsidiary structures, including a small hospital, a carpenter's shop, and a smithy, were constructed to the north side of the fort. In the early 1830s, the yard on the north side of the fort was enclosed by a wooden palisade. As early as 1826, however, Castle Pinckney was being referred to as an "auxiliary," rather than primary, component of Charleston's harbor defenses (Ziegler [11]). And with the commencement, in 1829, of the construction of the larger and more substantial Fort Sumter, a permanent system fort at a more strategic location near the mouth of the harbor, Castle Pinckney's impending obsolescence was made evident.

\subsubsection{Castle Pinckney during the Civil War}

On 20 December 1860, South Carolina became the first state to secede from the Union, precipitating the American Civil War (1861-65). Seven days later, in one of the first hostile actions of the incipient conflict, Castle Pinckney was seized by local secessionists, who overwhelmed its small federal garrison. The fort was then occupied by South Carolina militia. Following the First Battle of Manassas in July 1861, Union prisoners were brought to Castle Pinckney, and housed there until their exchange in October of that year. Over the subsequent course of the war, Castle Pinckney's exterior walls were reinforced with massive earthen berms on both the interior and the exterior to resist bombardment, as the fort served an integral role in the Confederate defense of Charleston Harbor (Ziegler [12]).

\subsubsection{Castle Pinckney, 1865-2011}

A light beacon had been installed at Castle Pinckney in 1855 and, following the end of the War, the fort, by then officially obsolete as a military post, was transferred from the Department of War to the Lighthouse Bureau of the Department of the Treasury in 1878 for use as a supply depot. During the 1880s a large warehouse was constructed on the filled-in fort, connected by a railroad trestle to the island's wharf, along with a house for the lighthouse keeper and his family. In 1917 Castle Pinckney was deaccessioned by the Lighthouse Board and returned to the Department of the Army, under the control of the Corps of Engineers. Castle Pinckney was designated a National Monument in 1924, and transferred to the control of the National Park Service (NPS) in 1933. The NPS, however, lacked funds for restoration and deemed the fort of minor historical importance. In 1956 the fort's National Monument status was revoked by Congress. That same year the South Carolina State Ports Authority assumed jurisdiction over Shute's Folly Island. In 1967 the warehouse and residence 
were destroyed by fire. Although a number of proposals for development of the island and the fort were put forward during the second half of the twentieth century, all failed due to lack of funding (Ziegler [13]).

\section{The documentation of Castle Pinckney}

\subsection{The documentation project partners}

\subsubsection{The Historic American Buildings Survey}

The Historic American Buildings Survey (HABS) was established in 1933, under the administration of President Franklin D. Roosevelt, as a government program to employ out-of-work architects during the Great Depression. As such, HABS was the first, and remains the oldest, United States government historic preservation program. Teams of architects were assembled in regional offices across the country, to produce measured drawings, large-format photographs, and historical reports of historic buildings, structures, and landscapes. In 1934 a tripartite agreement was signed between the National Park Service (NPS), the government agency which agreed to run the program; the American Institute of Architects, who agreed to provide professional oversight; and the Library of Congress, who agreed to establish archival standards for the documentation and to house the collection and make it available to the public. Today, the Collections of HABS and its two sister programs, the Historic American Engineering Record (established 1969) and the Historic American Landscapes Survey (established 2000), constitute more than 64,000 sheets of measured drawings, 245,000 pages of history, and 284,000 photographs - one of the largest architectural archives in the world.

HABS has a long and productive history of working with students through colleges and universities. HABS has operated a well-known summer internship program, dating back to the 1950s, where college students are employed on documentation projects across the country. In 1983, on the program's 50th anniversary, HABS established the Charles E. Peterson Prize Competition, an annual student competition of measured drawings. To date, the competition has resulted in the participation of more than 2,700 students, the donation of more than 5,800 sheets of drawings to the collection, and the disbursement of more than $\$ 140,000$ in prize money.

\subsubsection{The Master of Science in Historic Preservation Program}

The Master of Science in Historic Preservation (MSHP) Program, jointly administered by Clemson University and the College of Charleston, was established in 2005. The program is based in Charleston, South Carolina, one of the most architecturally rich and well preserved cities in the United States. The environs serve as a laboratory for the students, who collaborate and volunteer with many preservation programs and professionals throughout the community. Architectural documentation is an essential component of the 54 credit hour graduate curriculum. With students from a wide variety of undergraduate backgrounds (mostly non-design fields), documentation is seen as the 
fundamental tool to acquire an understanding of building technology, architectural history, and materials performance. Documentation as a teaching tool also gives back to the community, as buildings within the region are recorded and drawings submitted to the Library of Congress. With this emphasis on documentation methodologies, MSHP student entries have won a number of Peterson Prizes in recent years.

\subsection{The Castle Pinckney documentation project}

The proposal to undertake a documentation project of Castle Pinckney dates from author Schara's first visit to Charleston in 2006, at the invitation of Professor Wilson to speak to her documentation class. The visit included a trip on the boat used to ferry tourists to Fort Sumter, which passes by Shute's Folly Island, during which the author first noticed Castle Pinckney. The project was slowly developed over the course of subsequent annual visits. The parameters of the project were eventually determined: HABS staff members would travel from Washington, D.C. to Charleston, bringing the office's Leica Scanstation 2 threedimensional laser scanner. The HABS team would document the fort using laser scanning, assisted by MSHP students undertaking supplemental hand measurements. Thus not only would the fort be recorded, but the students would participate in the project and receive exposure to the laser scanning technology. Subsequently, several selected MSHP students would travel to the HABS Washington office, using the office's facilities and software to produce the final measured drawings. In addition, one of the students would produce a HABS historical report. Ultimately the aims of the project were threefold: to produce documentation of an important historic structure, to provide an educational experience for students, and to bring attention to a significant but neglected historic resource.

Three major challenges remained before the project to document Castle Pinckney could be undertaken. Permission was needed from the island's owner, the South Carolina State Ports Authority (SPA), for access. Boat transportation was required to ferry team members and their supplies to and from the island. And a source of funding was needed to subsidize the travel costs of the HABS team. The Historic Charleston Foundation (HCF), although unable to commit funds, was brought on board to provide support. The superintendent of Fort Sumter National Monument (FOSU), the NPS unit which manages the other two major historic forts in Charleston, Fort Moultrie and Fort Sumter, committed the use of one of the park's boats, along with an operator. And finally, in 2010 the MSHP program was able to provide the HABS team travel costs.

On 30 November 2010, a team consisting of the authors, the FOSU superintendent, and the HCF associate director of preservation, made a first reconnaissance visit to Castle Pinckney. It was immediately determined that the excessive overgrowth on the fort would impede the laser-scanning process. After meeting with the SPA and obtaining permission to undertake the project, another state agency, the Department of Natural Resources, was engaged to assist in selective vegetation removal at the fort. This was undertaken, with MSHP student assistance, 4 February 2011. 


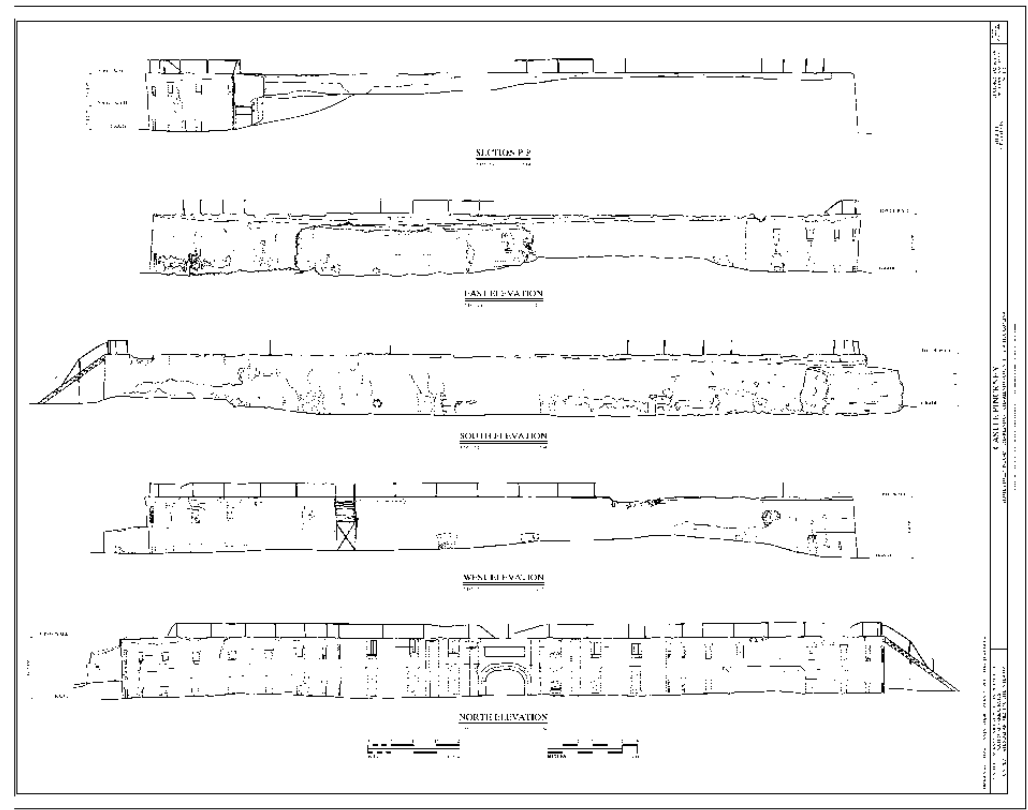

Figure 2: Elevations and section of Castle Pinckney, Drawing by L. Cunningham, R. Pierce and D. Weirick, 2011, HABS No. SC195 (Library of Congress).

On 21-25 February 2011, a team of four HABS staff members (two architects, a photographer, and a historian) traveled to Charleston to undertake the documentation of Castle Pinckney. An early spring date was chosen so that the laser scanning could be executed before the remaining vegetation leafed out and before birds migrated north for nesting. The logistics of the project remained challenging. FOSU provided a small boat, known as a Boston Whaler, which could get relatively close to the island's shore, but which necessarily limited the number of people and amount of equipment which could be brought on any one trip, thus requiring numerous trips. Since the island lacks a dock, it was necessary to wade in from the boat, laboriously carrying all of the equipment (some of it quite heavy and quite valuable). Nonetheless, the availability of the boat provided a rare opportunity for not only the HABS team and the MSHP students to visit the island, but also for others from the Charleston preservation community.

The HABS architects spent three full days on the island. The laser scanning of Castle Pinckney was captured from twelve stations, six at ground level around the exterior of the fort, and another six by traversing the top of the walls. As an adjunct to the laser scanning, high dynamic range panoramic photography was also undertaken. The HABS photographer spent two days on the island, and took twenty-one large format, archival black and white photographs. The 


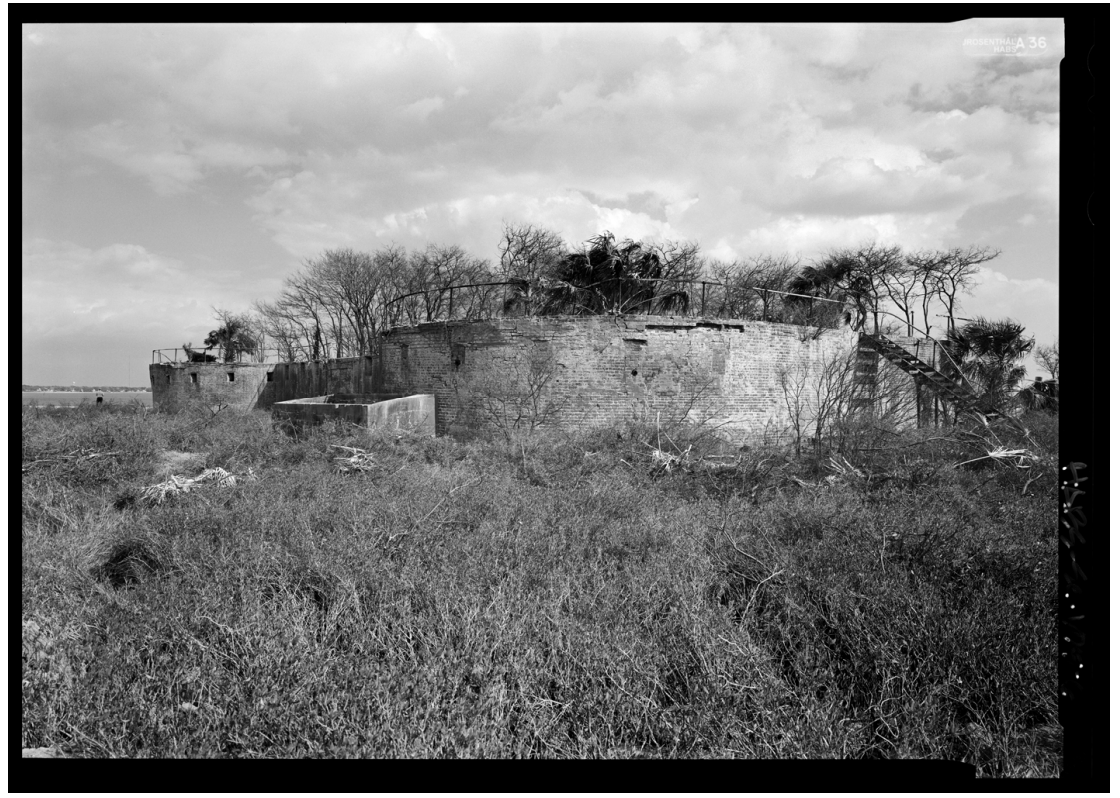

Figure 3: View of Castle Pinckney, looking east. Photograph by J. Rosenthal, 2011, HABS No. SC-195-6 (Library of Congress).

historian investigated various archives and collections in Charleston related to the site. The HABS project received substantial publicity, including a front page story in the local newspaper, The Post and Courier, a segment on the nightly news (WCBD), and even mention in the national newspaper USA Today [14].

Subsequently, during the summer of 2011, three MSHP students worked in the HABS Washington office to undertake the measured drawings, working from the laser scan point cloud and from the student field notes. Four sheets of drawings were produced, including a site plan, a plan, four elevations, and a section. In addition, the students worked with the HABS historian to research the history of Castle Pinckney, using the unique resources of the Library of Congress and the National Archives in Washington. As a result of this experience, one of the students will be writing his thesis for the MSHP program on Castle Pinckney.

\section{The future of Castle Pinckney}

\subsection{Current conditions}

The future of Castle Pinckney remains uncertain and problematic. In 2011 the fort was sold by the SPA to the Sons of Confederate Veterans (SCV) for a nominal ten dollars. The SCV had, in fact, previously owned the fort (1968-84), but were unable during that time to raise the funds necessary to undertake any projects at the site. The current plans by the SCV for the site remain unknown, 
and any proposal to use Castle Pinckney to promote the Confederate cause would undoubtedly be controversial for a large segment of the American public.

In any case, any effort to make Castle Pinckney accessible to the public, or to adaptively reuse the site, faces significant obstacles. First and foremost is the fort's location, on an island in the harbor, requiring boat transportation to access the site. There is no dock on Shute's Folly Island. The island itself is low-lying and marshy, and covered with a dense low growth which is not amenable to pedestrian activities. The fort itself, its interior completely filled with earth, presents little of obvious, outward historic interest. Which structures or foundations may survive under the fill is unknown. Extensive archaeology would be required in the fort's interior to expose these remains.

The National Park Service (NPS), the nation's leading cultural resource management agency, would seem to be the obvious steward for Castle Pinckney and, in fact, the NPS had jurisdiction over the site from 1933 to 1956 . However, the NPS already manages the other two major surviving forts in Charleston Harbor, Fort Moultrie and Fort Sumter. Fort Moultrie, a second system "star" fort begun the same year as Castle Pinckney (1809), remained as a United States military post until after World War II, and thus was transferred to the NPS in good physical condition. Located on Sullivan's Island near the mouth of Charleston Harbor, the fort is easily accessible by automobile via a causeway. Fort Sumter, begun in 1829 on a shoal in the harbor opposite Fort Moultrie, was bombarded into ruins during the Civil War. However, the fort's role as the target of the war's opening salvo (12-13 April 1861) has given Fort Sumter an outsize historical importance in American popular culture, in relation to its military significance. Providing access to Fort Sumter has required the construction of a large dock at the fort and the implementation of a ferry service. Despite these logistical difficulties, nearly 800,000 tourists visited Fort Sumter in 2010 [15]. Castle Pinckney lacks the easy access of Fort Moultrie and the compelling historical narrative of Fort Sumter. And given the current climate of fiscal restraint being imposed on the United States government, it is difficult to imagine the NPS assuming control over the site.

Although the walls of Castle Pinckney have survived relatively intact, especially considering its exposed location, there are unmistakable signs of slow, steady deterioration at the site. Large cracks can be seen in the walls in several locations, and there are a number of locations where bricks have fallen out. Vegetation remains a problem, with numerous plants, and even trees, growing out of the top of the walls. Charleston is prone to hurricanes, with the city suffering, on average, one a decade. Hurricane Hugo in 1989 caused seven billion dollars in damage and 26 deaths [16]. Likewise, the rise in sea level due to global climate change will undoubtedly have an adverse impact on Castle Pinckney. Although the seaward side of the fort is protected with rip-rap put in place by the SPA, water at high tide nonetheless reaches the bottom of the fort's walls. 


\subsection{The Castle Pinckney student competition}

In 2012. due to the efforts of Professor Wilson, of the American Institute of Architects' Historic Resources Committee (AIA/HRC), and of the American Collegiate Schools of Architecture (ACSA), an international ideas competition for Castle Pinckney, titled "Preservation as Provocation," will be launched. The intent of the competition is to challenge students in multi-disciplinary teams in the fields of architecture, preservation, landscape architecture, urban planning, engineering and other cross-disciplines, to rethink the abandoned early nineteenth century fort. Participants will be asked to preserve and interpret the extant historic fabric as emblematic of the country's early attempt to create a national defense system, and to re-imagine the site as an eco-tourist and educational destination. Solutions will be encouraged to explore the issues of access, the relationship between preservation and design (both architectural and landscape), off-grid energy consumption, changing climate patterns, water management, land use, and habitat protection. It is intended that the students will investigate how the preservation of this historically significant site can provoke a profound rethinking of our current conventions about preservation, design, community, the environment, and heritage tourism.

The Preservation as Provocation Competition will be promoted by the ACSA to the more than 5,000 architecture faculty members and more than 30,000 architecture students across the country. The competition will take place during the 2012-13 academic year. A jury of experts will convene during the summer of 2013 to select a winner.

\section{References}

[1] The Mayor's Walled City Task Force, www.walledcitytaskforce.org/educational-resources/time-line/

[2] Robinson, W. B., American Forts, Architectural Form and Function, University of Illinois Press: Urbana, Chicago and London, p.56, 1977.

[3] Robinson, p. 63; and Lewis, E. R., Seacoast Fortifications of the United States: An Introductory History, Smithsonian Institution Press: Washington, pp.21-25, 1970.

[4] Ziegler, C. T., "The Origins and Development of America's Forgotten Castle: Castle Pinckney," M.A. thesis, University of South Carolina, pp.13$17,2007$.

[5] National Historic Landmark Nomination for Fort James Jackson, http://pdfhost.focus.nps.gov/docs/NHLS/Text/70000200.pdf, pp.9-10.

[6] Robinson, pp.85-86.

[7] Ziegler, pp.18-25.

[8] U.S. Army Corps of Engineers, Headquarters, History, http:/www.usace.army.mil/History/Pages/Commanders.aspx

[9] Lewis, pp.31-32; Robinson, pp. 74-77; and Hightower, B., "Governors Island, Castle Williams," HABS No. NY-5715-2, Historic American 
Buildings Survey, National Park Service, U.S. Department of the Interior, http://www.loc.gov/pictures/collection/hh/item/ny1492/

[10] Ziegler, pp.36-49; and U.S. Army, History, http://www.history.army.mil/ books /CG\&CSA/Macomb-A.htm

[11] Ziegler, p.51.

[12] Ziegler, pp.55-64; and Castle Pinckney, http://en.wikipedia.org/wiki /Castle_Pinckney

[13] Ziegler, pp.65-71.

[14] "National Park Service records Castle Pinckney with high-tech equipment," http://www.postandcourier.com/news/2011/feb/23/measuring-a-localtreasure/; and "Researchers Study Castle Pinckney in Charleston Harbor," http://www2.counton2.com/news/2011/feb/23/researchers-study-castlepinckney-charleston-harbo-ar-1498706/

[15] National Park Service Statistical Abstract 2010, http://www.nature.nps.gov/ socialscience/docs/PUSO_Abstract_2010.pdf

[16] Hurricane City, http://www.hurricanecity.com/city/charleston.htm 